\title{
Sequential Treatment with Taxanes and Novel Anti-Androgenic Compounds in Castration-Resistant Prostate Cancer
}

\author{
Lukas Esch Wolfgang A. Schulz Peter Albers \\ Department of Urology, University Hospital Düsseldorf, Heinrich-Heine University, Düsseldorf, Germany
}

\section{Keywords}

Chemoresistance $\cdot$ Hormonal treatment - Prostate cancer . Sequential chemotherapy

\section{Summary}

Several novel therapeutic agents have demonstrated ability to improve overall survival in metastatic castration-resistant prostate cancer (mCRPC) in recent years. With as many as 5 new agents approved within the last 5 years and an ongoing lack of comparative and prospective data, strategies for patient selection and sequencing of drug treatments are urgently needed. This review will summarize current clinical evidence and relevant molecular mechanisms in mCRPC. The understanding of these mechanisms may provide valuable assistance in making therapeutic decisions, especially while robust clinical data remain sparse.

\section{Introduction}

A decade ago, docetaxel-based chemotherapy regimens were shown to provide an overall survival (OS) benefit to patients with metastatic castration-resistant prostate cancer (mCRPC) over preceding regimes such as mitoxantrone plus prednisone [1]. Subsequently, docetaxel became established as the standard 1st-line chemotherapy in this population. Fortunately, advances in clinical research have resulted in the approval of several new treatment options for mCRPC in the last 5 years. Today, clinicians can choose among several different agents approved for treating mCRPC patients: immunotherapeutic vaccines (sipuleucel-T), chemotherapy (docetaxel and cabazitaxel), novel anti-androgens (abiraterone acetate and enzalutamide), and radiopharmaceuticals (radium-223, only for patients with bone metastases). Although these novel therapeutic agents have all been demonstrated to improve OS in randomized phase III trials, no comparative trials have been published so far. Furthermore, robust prospective data regarding optimal sequencing of these treatments is lacking. This article will summarize the current clinical evidence for sequencing of taxanes and novel anti-androgens. At the same time, our current understanding of the molecular mechanisms leading to CRPC will also be taken into account. This insight may provide valuable additional support for making therapeutic decisions while clinical evidence remains sparse at this point.

\section{Molecular Pathophysiological Aspects of CRPC}

Although CRPC may in principle arise through loss of dependency on the function of the androgen receptor (AR) [2], most mechanisms identified to date confer resistance to antiandrogenic therapy by supporting the function of the AR. A variety of mechanisms have been identified, including point mutations in the AR ligand-binding domain that broaden its specificity to include various steroids [3], amplification of the AR gene with consequent overexpression [4], activation of upstream signaling pathways that diminish AR ligand dependency, especially of the IL-6 pathway [5], and changes in AR coactivators [6]. More recently, further mechanisms have been added to this list, including altered crosstalk with the PI3K/ AKT pathway [7], autonomous intratumoral androgen biosynthesis [8], upregulation of AR expression (e.g. as a consequence of RB1 loss) [9], and altered expression of AR transcriptional cofactors such as FOXA1 [10]. The significance of these changes was highlighted by recent molecular analyses of

\section{KARGER \\ Fax +497614520714 \\ Information@Karger.com}

www.karger.com (c) 2014 S. Karger GmbH, Freiburg $2296-5270 / 14 / 0379-0492 \$ 39.50 / 0$

Accessible online at: www.karger.com/ort
Peter Albers, MD

Department of Urology, University Hospital Düsseldorf

Heinrich-Heine University

Moorenstr. 5, 40225 Düsseldorf, Germany

urologie@uni-duesseldorf.de 
Table 1. Studies on sequential therapies in metastatic castration-resistant prostate cancer (mCRPC); of note: the following studies are displayed in one chart solely for the sake of clarity. As their setting is highly heterogeneous in nature, results should not be compared directly

\begin{tabular}{|c|c|c|c|c|}
\hline Study setting & Type of study & Patients, $\mathrm{n}$ & PFS / OS, months & Reference \\
\hline Doc activity after AA therapy & retrospective analysis & 35 & $4.6 / 12.5$ & [37] \\
\hline $\begin{array}{l}\text { Doc activity with and without } \\
\text { prior AA therapy }\end{array}$ & retrospective analysis & 119 (Doc: 95; AA-Doc: 24) & 7.6 (Doc) vs. 4.4 (AA-Doc) / n.a. & {$[38]$} \\
\hline $\begin{array}{l}\text { AA and Cab activity after Doc } \\
\text { therapy }\end{array}$ & retrospective analysis & 42 (Doc-AA: 18; Doc-Cab: 24) & n.a./ 8 (Doc-AA) vs. 18 (Doc-Cab) & {$[33]$} \\
\hline $\begin{array}{l}\text { Enz activity after sequential Doc } \\
\text { and AA therapy }\end{array}$ & retrospective analysis & 61 & $2.8 / 7.3$ & {$[44]$} \\
\hline $\begin{array}{l}\text { Enz activity after sequential Doc } \\
\text { and AA therapy }\end{array}$ & retrospective analysis & 35 & $\begin{array}{l}4.0(\mathrm{n}=18 / 35 \text {; primarily resistant: } \\
\mathrm{n}=17 / 35) / 7.1(\mathrm{n}=35)\end{array}$ & {$[42]$} \\
\hline $\begin{array}{l}\text { Enz activity after sequential Doc } \\
\text { and AA therapy }\end{array}$ & prospective analysis & 35 & $3.1 / 7.5$ & {$[43]$} \\
\hline $\begin{array}{l}\text { Enz activity after sequential Doc } \\
\text { and AA therapy }\end{array}$ & retrospective analysis & 39 & $2.8 /$ n.a. & {$[41]$} \\
\hline $\begin{array}{l}\text { AA activity after sequential Doc } \\
\text { and Enz therapy }\end{array}$ & retrospective analysis & 38 & $2.7 / 7.2$ & {$[39]$} \\
\hline $\begin{array}{l}\text { AA activity after sequential Doc } \\
\text { and Enz therapy }\end{array}$ & retrospective analysis & $30 \mathrm{ww}$ & $3.5 / 11.5$ & {$[40]$} \\
\hline $\begin{array}{l}\text { Cab activity after sequential Doc, } \\
\text { AA, and/or Enz therapy }\end{array}$ & retrospective analysis & $\begin{array}{l}41 \text { (Doc-AA-Cab: 32; Doc-AA- } \\
\text { Enz-Cab: 5; Doc-Enz-Cab: 4) }\end{array}$ & $4.6 / 15.8$ & {$[45]$} \\
\hline $\begin{array}{l}\text { Cab activity after sequential Doc } \\
\text { and AA therapy }\end{array}$ & retrospective analysis & 79 & $4.4 / 10.9$ & {$[46]$} \\
\hline
\end{tabular}

Doc = Docetaxel; $\mathrm{Cab}=$ cabazitaxel; $\mathrm{AA}=$ abiraterone acetate; Enz = enzalutamide; $\mathrm{n} . \mathrm{a} .=$ not applicable.

CRPC genomes for copy number changes and point mutations $[11,12]$. Yet another - albeit likely not the last - mechanism involves upregulation of natural or mutant splice variants of the AR that lack the ligand-binding $\mathrm{C}$-terminal transactivation domain [13].

The variety of resistance mechanisms converging on the AR underlines the importance of this protein for the growth and survival of advanced-stage prostate cancers and provides a compelling rationale for targeting its activity. The new generation of anti-androgenic drugs has been designed on this basis, but moreover, their development has taken specific resistance mechanisms into account. Thus, enzalutamide (MDV-3100) was initially developed and tested on a cell line engineered to overexpress the AR, thereby mimicking gene amplification [14]. Only later did it turn out that the compound also prevented AR transport into the nucleus in addition to interfering with coactivator binding and transactivation. In a similar fashion, the development of abiraterone was driven by the recognition that advanced prostate cancers may synthesize the androgens they require autonomously. Docetaxel was initially used on the assumption that interference with microtubule dynamics should block prostate cancer cell proliferation [15]. Only much later came the surprising insight that taxanes actually interfere with androgen signaling via the nuclear translocation process [16].

It is particularly surprising to which extent AR splice variants have emerged in clinical studies and model systems as factors of resistance. These AR splice variants lack the ligand- binding domain and display constitutive activity. Some variants appear to represent natural endogenous mRNA isoforms that become upregulated as a consequence of altered regulation of splicing [17] caused in particular by loss of feedback inhibition by the full-length AR [18]. In such cases, blocking the function of the wild-type AR will lead to upregulation of the ligand-independent variant. In other cases, the variants arise by deletions or duplications in 1 copy of the AR gene in CRPC tumors [19]. Thus, this mechanism of resistance may be favored following gain or amplification of the AR gene. However, the ability of these splice variants to confer resistance is not limited to anti-androgenic therapy with enzalutamide and abiraterone $[20,21]$. Taxane activity is believed to be at least partly based on its ability to inhibit the nuclear translocation of the AR-ligand complex [22-24]. Recent studies have now revealed that AR splice variants also determine taxane sensitivity in prostate cancer [25]. While nuclear accumulation and transcriptional activity of one common splice variant (ARv7) was unaffected by taxane treatment, sufficient antitumor efficacy was retained with another variant (ARv567).

This study provides an elegant pathophysiological explanation for the cross-resistance of taxanes and novel anti-androgen therapeutics, and suggests a biomarker that could help predict the clinical activity of taxanes in individual CRPC patients. Patients presenting with an adverse splice-variant profile could be spared the taxane-based chemotherapy and be offered alternative treatment options. 


\section{Options for Sequential Treatment after Treatment with Docetaxel or Abiraterone}

The following section will gather the current clinical evidence for sequencing of taxanes and novel anti-androgens in the 2nd- and 3rd-line setting (table 1). After 1st-line docetaxel treatment, at this time, 3 other drugs represent alternatives, namely cabazitaxel, abiraterone and enzalutamide. In addition, there is some evidence supporting rechallenge with docetaxel.

\section{Sequence Options after 1st-Line Docetaxel Treatment}

There is sufficient scientific evidence from large retrospective studies that patients who demonstrate relevant prostatespecific antigen (PSA) response (i.e. $\geq 30 \%$ over at least 8 weeks) during initial docetaxel-based chemotherapy might be suitable for docetaxel re-exposure which leads to response rates of around 55-60\% without increasing treatment-related toxicity. At this point, there is still a lack of prospective data investigating this course of action and no proof of benefit with respect to OS [26-30].

The second-generation tubulin-targeting taxane cabazitaxel is as potent as docetaxel in cell line models. Additionally, the drug has antitumor activity in models resistant to paclitaxel and docetaxel. It was approved as 2nd-line treatment for CRPC patients based on the results of the TROPIC trial. This randomized open-label phase III study compared the efficacy and safety of cabazitaxel plus prednisone versus mitoxantrone plus prednisone in men with MCRPC with progressive disease after docetaxel-based treatment. It reported a significant benefit in terms of OS for cabazitaxel versus mitoxantrone (median OS 15.1 vs. 12.7 months) and also favored cabazitaxel in all secondary endpoints such as progression-free survival (PFS), PSA-response, and safety [31].

Based on the results of the COU-301 trial, abiraterone plus prednisone was approved as 2nd-line treatment for mCRPC patients after docetaxel-based chemotherapy. Following randomization to abiraterone-prednisone and placebo-prednisone, the abiraterone arm showed a significant OS benefit of 3.9 months (14.8 vs. 10.9 months), with all secondary end points including time to PSA progression (10.2 vs. 6.6 months), PFS (5.6 vs. 3.6 months), and PSA response rate ( 29 vs. $6 \%$ ) favoring the treatment group [32]. There is overall insufficient data on sequential treatment with abiraterone, as its antitumor activity in 1st- and 2nd-line settings has not yet been directly compared. However, there is some evidence from 2 smaller retrospective studies favoring cabazitaxel over abiraterone as 2nd-line option after docetaxel: Patients who received cabazitaxel demonstrated a benefit in OS (median OS 18 months with cabazitaxel vs. 8 months with abiraterone) and were more likely to receive subsequent abiraterone [33,34]. Additionally, subset analyses of TROPIC and COU-301 populations sug- gested several prognostic factors that could further influence the optimal choice of treatment after docetaxel. Cabazitaxel demonstrated a survival benefit especially in young mCRPC patients ( $<65$ years) with high Gleason scores (7-10) as well as in patients suffering from visceral metastases (lung and liver) $[31,35]$. In contrast, abiraterone has been proven beneficial in elderly patients (> 75 years) without visceral metastases and high Gleason scores of 8-10 [32].

Enzalutamide was approved as post-docetaxel treatment for mCRPC in 2012 after having demonstrated a median OS benefit of 4.8 months compared to placebo in the AFFIRM trial (18.4 vs. 13.6 months in the placebo group). The enzalutamide arm was also superior in all secondary end points such as PSA decrease $>50 \%$ (54 vs. $2 \%$ in the placebo arm), quality of life improvement (43 vs. 18\%), and soft tissue responses (29 vs. $4 \%$ ) [36].

\section{Sequence Options after 1st-Line Abiraterone Treatment}

Since docetaxel has been standard chemotherapy for CRPC until recently, there are only a limited number of studies on 2nd-line therapy following treatment with novel anti-androgens. There is limited data regarding the sequential use of docetaxel in abiraterone-resistant and -refractory patients. Retrospective data from a small cohort study $(\mathrm{n}=35)$ hinted at cross-resistance between abiraterone and docetaxel that could lead to decreased response rates and decreased time to progression compared to 1st-line docetaxel results from the TAX-327 trial ( $\geq 50 \%$ PSA declines in 26 vs. $45-48 \%$ ) [37]. In this study, no responses to docetaxel were observed in abiraterone-refractory patients. More recently, another small retrospective analysis assessed the influence of prior abiraterone treatment on the clinical activity of docetaxel in men with mCRPC [38]. It confirmed prior results concluding that men receiving abiraterone before docetaxel were more likely to progress on docetaxel and less likely to achieve a PSA response than abiraterone-naive patients (median PFS in pretreated group 4.4 vs. 7.6 months; PSA declines $\geq 50 \%$ was 38 vs. $63 \%$ ). This study thereby underlined the possibility of crossresistance between abiraterone and docetaxel.

\section{3rd-Line Treatment in Castration-Resistant Prostate Cancer}

None of the available treatments have been formally tested in 3rd-line settings. Their use is solely based on very limited and partly preliminary data. The relevant data for abiraterone, enzalutamide, and cabazitaxel in 3rd-line therapy are summarized in the following paragraphs.

A small cohort study investigated antitumor activity of abiraterone in $38 \mathrm{mCRPC}$ patients progressing after docetaxel and enzalutamide [39]. It reported only modest abiraterone 
Table 2. Current trials on castration-resistant prostate cancer (CRPC) drug treatment

\begin{tabular}{|c|c|c|c|c|c|}
\hline Intervention & Setting & Status & Primary endpoint & Trial name & Reference \\
\hline $\begin{array}{l}\text { Abiraterone plus ADT vs. ADT alone in } \\
\text { newly diagnosed high-risk mHNPC }\end{array}$ & mHNPC & phase III & OS & & NCT01715285 \\
\hline Cabazitaxel vs. docetaxel & 1st-line treatment & phase III & OS & FIRSTANA & NCT01308567 \\
\hline Enzalutamide vs. bicalutamide & $\begin{array}{l}\text { mCRPC post-LHRH failure } \\
\text { or bilateral orchiectomy }\end{array}$ & phase II & PFS & STRIVE & NCT01664923 \\
\hline Enzalutamide in hormone-naive PC & hormone-naive PC & phase II & PSA response & & NCT01302041 \\
\hline Enzalutamide after abiraterone in mCRPC & $\begin{array}{l}\text { 2nd-/3rd-line mCRPC post } \\
\text { abiraterone }\end{array}$ & phase IV & rPFS & & NCT02116582 \\
\hline Enzalutamide in non-metastatic CRPC & $\begin{array}{l}\text { non-metastatic CRPC/ } \\
\text { chemonaive }\end{array}$ & phase III & $\begin{array}{l}\text { metastasis-free } \\
\text { survival }\end{array}$ & PROSPER & NCT02003924 \\
\hline
\end{tabular}

$\mathrm{ADT}=$ Androgen deprivation therapy $; \mathrm{PC}=$ prostate cancer $;(\mathrm{r}) \mathrm{PFS}=$ (radiographic) progression-free survival; $\mathrm{PSA}=$ prostate-specific antigen; $\mathrm{OS}=$ overall survival; $\mathrm{mHNPC}=$ metastatic hormone-naive prostate cancer; $\mathrm{LHRH}=$ luteinizing hormone-releasing hormone; $\mathrm{mCRPC}=$ metastatic castration-resistant prostate cancer.

activity with a PSA response $\geq 50 \%$ in 3 of 38 patients or $8 \%$ compared to $29 \%$ in the 2 nd-line setting and $62 \%$ in the 1 stline setting. Only 1 of 17 patients not responding to prior 2 ndline enzalutamide treatment showed a PSA response $\geq 50 \%$ under subsequent 3rd-line abiraterone treatment.

In another multicenter review, a total of 30 patients treated with abiraterone acetate and prednisone after progressing on enzalutamide were assessed [40]. Similarly, limited abiraterone activity in the 3rd-line setting was observed. There were no objective radiographic responses, median time to progression (PSA, objective or symptomatic) was 15.4 weeks, while median OS was 50.1 weeks. 3 patients had a $\geq 30 \%$ PSA decline with abiraterone. 2 of these patients with prior enzalutamide had PSA progression as best response. These observations indicate superior responses in chemotherapy-naive patients, and again hint at the existence of cross-resistance between docetaxel, enzalutamide, and abiraterone.

Until now, only few retrospective cohort analyses have examined enzalutamide activity after docetaxel and abiraterone. Bianchini et al. [41] recently reported only limited enzalutamide activity in this setting (median PFS 2.8 months; PSA response $>50 \%$ in 5 of 39 patients, of which 2 had not previously responded to abiraterone). Another retrospective study with 35 patients previously reported PSA responses $>50 \%$ in $29 \%$ of patients with a median OS of 7.1 months and $16 \%$ (3/19) abiraterone-refractory patients responding to enzalutamide [42]. A small prospective study in 35 patients recently confirmed these latter findings with median OS rates of 7.5 months and median PFS (assessed by imaging) of 3.1 months [43]. Finally, the largest retrospective cohort analysis to date with a total of 61 patients further substantiated these results (median PFS 12.0 weeks, median OS 31.6 weeks) with favorable tolerability of enzalutamide in the 3rd-line setting [44]. The PSA responses to docetaxel and abiraterone did not predict the PSA response to enzalutamide.

Cabazitaxel also appears to retain relevant activity in the 3rd-line setting. In a retrospective analysis, Pezaro et al. [45] reported on a cohort of 59 men with progressing CRPC treated with cabazitaxel. 37 patients had received prior abiraterone, and 9 of these had received prior enzalutamide. After a median of 6 cabazitaxel cycles, $\geq 50 \%$ PSA declines were observed in 16 of 41 (39\%) evaluable patients, soft tissue radiologic responses were seen in 3 of 22 (14\%) evaluable patients, and symptomatic benefit was achieved in 9 of 37 (24\%) evaluable patients. Median OS and PFS were 15.8 and 4.6 months, respectively. Another recent retrospective analysis of 79 patients who were treated with cabazitaxel upon progression on docetaxel and abiraterone acetate overall confirmed prior results with slightly inferior outcome (median OS 10.9 months, PFS 4.4 months) [46].

\section{Ongoing Sequential Trials}

Though urgently needed, high-quality comparative trials evaluating these novel therapeutics are unlikely to be seen in the near future. Instead, a variety of - mostly industry-driven studies are under way aiming to expand approval of these novel drugs to non-metastatic CRPC or even hormone-naive disease stages (table 2).

\section{Mechanisms of Resistance and Clinical \\ Consequences}

With only limited and retrospective data available, choosing an optimal treatment sequence in CRPC remains challenging. Available clinical criteria have proven to be of only limited value, and reliable predictive markers are still a work in progress. The better understanding of the molecular mechanisms leading to disease progression has strengthened our perception of prostate cancer as a heterogeneous disease. Strong clinical evidence suggests the existence of cross-resistance between taxanes and novel anti-androgens like abiraterone and 


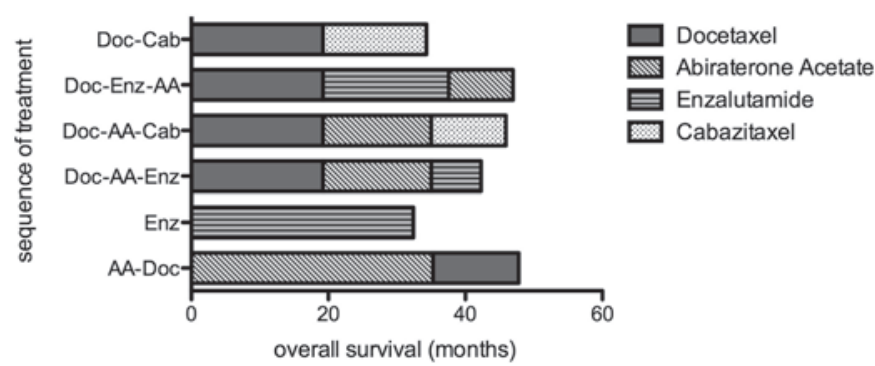

Fig. 1. Sequential therapy of metastatic castration-resistant prostate cancer (mCRPC). Comparison of the individual contribution of approved agents to overall survival in sequential use. Overall, the choice of 1st-line treatment appears most important, while 2nd- and 3rd-line show inferior results $($ Doc $=$ Docetaxel $;$ Enz $=$ enzalutamide; $\mathrm{AA}=$ abiraterone acetate $\mathrm{Cab}=$ cabazitaxel). Of note: results are displayed in one figure solely for the sake of clarity. As the underlying setting is highly heterogeneous in nature, results should not be compared directly.

enzalutamide. This observation is mechanistically plausible given their convergence on the AR. To date, it is not known to which extent their relative activity and, as a consequence, their cross-resistance are influenced by the type of molecular mech- anism underlying the emergence of CRPC in each individual case. Instead, there is evidence that some mechanisms of resistance to the novel compounds are effective even though they target different steps of androgen signaling. In more general terms, rapid incorporation of the understanding of the molecular mechanisms underlying resistance to anti-androgenic therapies appears sensible for making rational clinical decisions and avoiding ineffective treatments. In clinical practice, with the current lack of comparative trials and prospective studies regarding therapy sequences, all survival-prolonging treatments can be deemed valid. With all 2nd- and 3rd-line treatment options showing consistently inferior results, the optimal choice of 1st-line therapy remains of paramount importance when treating mCRPC (fig. 1). Furthermore, side effect profile and individual patient compliance continue to govern the management of this increasingly complex disease.

\section{Disclosure Statement}

Lukas Esch and Wolfgang A. Schulz both disclose no conflict of interest. Peter Albers received honoraria for lectures from Sanofi Oncology, Janssen Oncology, Dendreon, and Hexal Oncology in the last 3 years.

\section{References}

1 Tannock I, de Wit R, Berry W, Horti J, Pluzanska A, Chi K, Oudard S, Theodore C, James ND, Turesson I, Rosenthal MA, Eisenberger MA: Docetaxel plus prednisone or mitoxantrone plus prednisone for advanced prostate cancer. N Engl J Med 2004; 351:1502-1512.

2 Feldman BJ, Feldman D: The development of androgen-independent prostate cancer. Nat Rev Cancer 2001;1:34-45.

3 Veldscholte J, Berrevoets CA, Ris-Stalpers C, Kuiper GG, Jenster G, Trapman J, Brinkmann AO, Mulder E: The androgen receptor in LNCaP cells contains a mutation in the ligand binding domain which affects steroid binding characteristics and response to antiandrogens. J Steroid Biochem Mol Biol 1992;41:665-669.

4 Visakorpi T, Hyytinen E, Koivisto P, Tanner M, Keinänen R, Palmberg C, Palotie A, Tammela T, Isola J, Kallioniemi OP: In vivo amplification of the androgen receptor gene and progression of human prostate cancer. Nat Genet 1995;9:401-406.

$\checkmark 5$ Hobisch A, Eder IE, Putz T, Horninger W, Bartsch G, Klocker H, Culig Z: Interleukin-6 regulates prostate-specific protein expression in prostate carcinoma cells by activation of the androgen receptor. Cancer Res 1998;58:4640-4645.

6 Culig Z, Santer FR: Androgen receptor co-activators in the regulation of cellular events in prostate cancer. World J Urol 2012;30:297-302.

7 Mulholland DJ, Tran LM, Li Y, Cai H, Morim A, Wang S, Plaisier S, Garraway IP, Huang J, Graeber TG, Wu H: Cell autonomous role of PTEN in regulating castration-resistant prostate cancer growth. Cancer Cell 2011;19:792-804.

$\checkmark 8$ Chang KH, Li R, Papari-Zareei M, Watumull L, Zhao YD, Auchus RJ, Sharifi N: Dihydrotestosterone synthesis bypasses testosterone to drive castration-resistant prostate cancer. Proc Natl Acad Sci U S A 2011;108:13728-13733.
9 Sharma A, Yeow WS, Ertel A, Coleman I, Clegg N, Thangavel C, Morrissey C, Zhang X, Comstock CE, Witkiewicz AK, Gomella L, Knudsen ES, Nelson PS, Knudsen KE: The retinoblastoma tumor suppressor controls androgen signaling and human prostate cancer progression. J Clin Invest 2010;120: 4478-4492.

10 Gerhardt J, Montani M, Wild P, Beer M, Huber F, Hermanns T, Müntener M, Kristiansen G: FOXA1 promotes tumor progression in prostate cancer and represents a novel hallmark of castration-resistant prostate cancer. Am J Pathol 2012;180:848-861.

11 Friedlander TW, Roy R, Tomlins SA, Ngo VT, Kobayashi Y, Azameera A, Rubin MA, Pienta KJ, Chinnaiyan A, Ittmann MM, Ryan CJ, Paris PL: Common structural and epigenetic changes in the genome of castration-resistant prostate cancer. Cancer Res 2012;72:616-625.

12 Grasso CS, Wu YM, Robinson DR, Cao X, Dhanasekaran SM, Khan AP, Quist MJ, Jing X, Lonigro RJ, Brenner JC, Asangani IA, Ateeq B, Chun SY, Siddiqui J, Sam L, Anstett M, Mehra R, Prensner JR, Palanisamy N, Ryslik GA, Vandin F, Raphael BJ, Kunju LP, Rhodes DR, Pienta KJ, Chinnaiyan AM, Tomlins SA: The mutational landscape of lethal castration-resistant prostate cancer. Nature 2012;487:239-243.

13 Dehm SM, Tindall DJ: Alternatively spliced androgen receptor variants. Endocr Relat Cancer 2011; 18:183-196.

14 Tran C, Ouk S, Clegg NJ, Chen Y, Watson PA, Arora V, Wongvipat J, Smith-Jones PM, Yoo D, Kwon A, Wasielewska T, Welsbie D, Chen CD, Higano CS, Beer TM, Hung DT, Scher HI, Jung ME, Sawyers CL: Development of a second-generation antiandrogen for treatment of advanced prostate cancer. Science 2009;324:787-790.
15 Petrylak DP, Macarthur RB, O'Connor J, Shelton G, Judge T, Balog J, Pfaff C, Bagiella E, Heitjan D, Fine R, Zuech N, Sawczuk I, Benson M, Olsson CA: Phase I trial of docetaxel with estramustine in androgen-independent prostate cancer. J Clin Oncol 1999;17:958-967.

16 Gan L, Chen S, Wang Y, Watahiki A, Bohrer L, Sun $\mathrm{Z}$, Wang $\mathrm{Y}$, Huang $\mathrm{H}$ : Inhibition of the androgen receptor as a novel mechanism of taxol chemotherapy in prostate cancer. Cancer Res 2009;69: 8386-8394.

17 Liu LL, Xie N, Sun S, Plymate S, Mostaghel E, Dong X: Mechanisms of the androgen receptor splicing in prostate cancer cells. Oncogene 2014;33: 3140-3150.

$18 \mathrm{Yu}$ Z, Chen S, Sowalsky AG, Voznesensky OS, Mostaghel EA, Nelson PS, Cai C, Balk SP: Rapid induction of androgen receptor splice variants by androgen deprivation in prostate cancer. Clin Cancer Res 2014;20:1590-1600.

19 Nyquist MD, Dehm SM: Interplay between genomic alterations and androgen receptor signaling during prostate cancer development and progression. Horm Cancer 2013;4:61-69.

20 Mostaghel EA, Marck BT, Plymate SR, Vessella RL, Balk S, Matsumoto AM, Nelson PS, Montgomery RB: Resistance to CYP17A1 inhibition with abiraterone in castration-resistant prostate cancer: induction of steroidogenesis and androgen receptor splice variants. Clin Cancer Res 2011;17:5913-5925.

21 Li Y, Chan SC, Brand LJ, Hwang TH, Silverstein KA, Dehm SM: Androgen receptor splice variants mediate enzalutamide resistance in castration-resistant prostate cancer cell lines. Cancer Res 2013; 73:483-489.

22 Zhu ML, Horbinski CM, Garzotto M, Qian DZ, Beer TM, Kyprianou N: Tubulin-targeting chemotherapy impairs androgen receptor activity in prostate cancer. Cancer Res 2010;70:7992-8002. 
23 Darshan MS, Loftus MS, Thadani-Mulero M, Levy BP, Escuin D, Zhou XK, Gjyrezi A, Chanel-Vos C, Shen R, Tagawa ST, Bander NH, Nanus DM, Giannakakou P: Taxane-induced blockade to nuclear accumulation of the androgen receptor predicts clinical responses in metastatic prostate cancer. Cancer Res 2011;71:6019-6029.

24 Thadani-Mulero M, Nanus DM, Giannakakou: Androgen receptor on the move: boarding the microtubule expressway to the nucleus. Cancer Res 2012;72:4611-4615.

25 Thadani-Mulero M, Portella L, Sun S, Sung M, Matov A, Vessella RL, Corey E, Nanus DM, Plymate SR, Giannakakou P: Androgen receptor splice variants determine taxane sensitivity in prostate cancer. Cancer Res 2014;74:2270-2282.

-26 Caffo O, Pappagallo G, Brugnara S, Caldara A, Chiara di Pasquale M, Ferro A, Frisinghelli M, Murgia V, Russo LM, Soini B, Valduga F, Veccia A, Galligioni $\mathrm{E}$ : Multiple rechallenges for castration-resistant prostate cancer patients responding to firstline docetaxel: assessment of clinical outcomes and predictive factors. Urology 2012;79:644-649.

27 Heck MM, Thalgott M, Retz M, Wolf P, Maurer T, Nawroth R, Hatzichristodoulou G, Gschwend JE: Rational indication for docetaxel rechallenge in metastatic castration-resistant prostate cancer. BJU Int 2012;110:E635-640.

28 Loriot Y, Massard C, Gross-Goupil M, Di Palma M, Escudier B, Bossi A, Chauchereau A, Fizazi K: The interval from the last cycle of docetaxel-based chemotherapy to progression is associated with the efficacy of subsequent docetaxel in patients with prostate cancer. Eur J Cancer 2010;46:1770-1772.

29 Pfister D, Porres D, Piper C, Merseburger A, Klotz T, Heidenreich A: Comparison of second-line treatments in patients with castration-resistant prostate cancer with PSA relapse after or during docetaxel chemotherapy. J Clin Oncol 2012;30 (suppl 5):abstr 243

30 Heidenreich A, Bastian P, Bellmunt J, Bolla M, Joniau S, van der Kwast T, Mason M, Matveev V, Wiegel T, Zattoni F, Mottet N: EAU guidelines on prostate cancer. Part II: Treatment of advanced, relapsing, and castration-resistant prostate cancer. Eur Urol 2014;65:467-479.

31 De Bono J, Oudard S, Ozguroglu M, Hansen S, Machiels J, Kocak I, Gravis G, Bodrogi I, Mackenzie MJ, Shen L, Roessner M, Gupta S, Sartor O: Prednisone plus cabazitaxel or mitoxantrone for metastatic castration-resistant prostate cancer progressing after docetaxel treatment: a randomised openlabel trial. Lancet 2010;376:1147-1154.
32 De Bono J, Logothetis C, Molina A, Fizazi K, North S, Chu L, Chi K, Jones RJ, Goodman OB, Saad F, Staffurth JN, Mainwaring P, Harland S, Flaig TW, Hutson TE, Cheng T, Patterson H, Hainsworth JD, Ryan CJ, Sternberg CN, Ellard SL, Flechon A, Saleh M, Scholz M, Efstathiou E, Zivi A, Bianchini D, Loriot Y, Chieffo N, Kheoh T, Haqq C, Scher HI: Abiraterone and increased survival in metastatic prostate cancer. N Engl J Med 2011;364:1995-2005.

33 Malik ZI, Montazeri AH, Wong H, Eswarvee C: Post docetaxel treatment for castration-resistant prostate cancer (CRPC): does sequencing matter? J Clin Oncol 2012;30(suppl):abstr e15135.

34 Angelergues A, Maillet D, Flechon A, Ozguroglu M, Mercier F, Guillot A, Le Moulec S, Gravis G, Beuzeboc P, Massard C, De La Motte Rouge T, Elaidi R, Oudard S: Prognostic factors of survival in patients with metastatic castration resistant prostate cancer (mCRPC) treated with cabazitaxel: sequencing might matter. J Clin Oncol 2013; 31(suppl):abstr 5063

35 Madan RA, Pal SM, Sartor O, Dahut WL: Overcoming chemotherapy resistance in prostate cancer. Clin Cancer Res 2011;17:3892-3902.

36 Scher H, Fizazi K, Saad F, Taplin M, Sternberg C, Miller M, de Wit R, Mulders P, Chi KN, Shore ND, Armstrong AJ, Flaig TW, Flechon A, Mainwaring P, Fleming M, Hainsworth JD, Hirmand M, Selby B, Seely L, de Bono JS: Increased survival with enzalutamide in prostate cancer after chemotherapy. N Engl J Med 2012;367:1187-1197.

37 Mezynski J, Pezaro C, Bianchini D, Zivi A, Sandhu S, Thompson E, Hunt J, Sheridan E, Baikady B, Sarvadikar A, Maier G, Reid AHM, Mulick Cassidy A, Olmos D, Attard G, de Bono J: Antitumour activity of docetaxel following treatment with the CYP17A1 inhibitor abiraterone: clinical evidence for cross-resistance? Ann Oncol 2012;23:2943-2947.

38 Schweizer MT, Zhou XC, Wang H, Bassi S, Carducci MA, Eisenberger MA, Antonarakis ES: The Influence of prior abiraterone treatment on the clinical activity of docetaxel in men with metastatic castration-resistant prostate cancer. Eur Urol 2014; Epub ahead of print.

39 Loriot Y, Bianchini D, Ileana E, Sandhu S, Patrikidou A, Pezaro C, Albiges L, Attard G, Fizazi K, de Bono JS, Massard C: Antitumour activity of abiraterone acetate against metastatic castration-resistant prostate cancer progressing after docetaxel and enzalutamide (MDV3100). Ann Oncol 2013; 24:1807-1872.
40 Noonan K, North S, Bitting R, Armstrong A, Ellard S, Chi K: Clinical activity of abiraterone acetate in patients with metastatic castration-resistant prostate cancer progressing after enzalutamide. Ann Oncol 2013;24:1802-1807.

41 Bianchini D, Lorente D, Rodriguez-Vida A, Omlin A, Pezaro C, Ferraldeschi R, Zivi A, Attard G, Chowdhury S, de Bono JS: Antitumour activity of enzalutamide (MDV3100) in patients with metastatic castration-resistant prostate cancer (CRPC) pre-treated with docetaxel and abiraterone. Eur J Cancer 2014:50:78-84.

42 Schrader AJ, Boegemann M, Ohlmann C, Schnoeller TJ, Krabbe L, Hjili T, Jentzmik F, Stoeckle M, Schrader M, Herrmann E, Cronauer MV: Enzalutamide in castration-resistant prostate cancer patients progressing after docetaxel and abiraterone. Eur Urol 2013;65:30-36.

43 Schmid SC, Geith A, Böker A, Tauber R, Seitz AK, Kuczyk M, von Klot C, Gschwend JE, Merseburger AS, Retz M: Enzalutamide after docetaxel and abiraterone therapy in metastatic castration-resistant prostate cancer. Adv Ther 2014;31:234-241.

44 Badrising S, van der Noort V, van Oort IM, van den Berg HP, Los M, Hamberg P, Coenen JL, van den Eertwegh AJM, de Jong IJ, Kerver ED, van Tinteren H, Bergman AM: Clinical activity and tolerability of enzalutamide (MDV3100) in patients with metastatic, castration-resistant prostate cancer who progress after docetaxel and abiraterone treatment. Cancer 2014;120:968-975.

45 Pezaro C, Le Moulec S, Albiges L, Omlin A, Loriot Y, Bianchini D, Gross-Goupil M, Lorente D, de la Motte Rouge T, Bezeboc P, Attard G, Guillot A, Fizazi K, de Bono JS, Massard C: Response to cabazitaxel in CRPC patients previously treated with docetaxel and abiraterone acetate. J Clin Oncol 2013;31(suppl 6):abstr 155 .

46 Al Nakouzi N, Le Moulec S, Albiges L, Wang C, Beuzeboc P, Gross-Goupil M, de La Motte Rouge T, Guillot A, Gajda D, Massard C, Gleave M, Fizazi $\mathrm{K}$, Loriot Y: Cabazitaxel remains active in patients progressing after docetaxel followed by novel androgen receptor pathway targeted therapies. Eur Urol 2014; DOI: 10.1016/j.eururo.2014.04.015 Epub ahead of print. 